\title{
Pengaruh Penggunaan Gadget Terhadap Pola Pikir Siswa Kelas VIII SMP Negeri 2 Ulaweng Kecamatan Ulaweng Kabupaten Bone
}

\author{
Achmad Dahlan Abdullah \\ Universitas Muhammadiyah Bone \\ Email: achmaddahlanabdullah@gmail.com
}

\begin{abstract}
This research is a quantitative descriptive study that aims to determine the effect of using gadgets on the mindset of class VIII students of SMP Negeri 2 Ulaweng, Ulaweng District, Bone Regency. The population in this study were all class VIII students of SMP Negeri 2 Ulaweng, Ulaweng District, Bone Regency and the sample was all students of class VIIIA SMP Negeri 2 Ulaweng, Ulaweng District, Bone Regency with a total of 30 students consisting of 17 male students and 13 female students. Data collection techniques were carried out using three methods, namely, questionnaires (questionnaires), documentation and interviews. Based on the data analysis, it was obtained an overview of the effect of using gadgets on students' mindsets, the percentage of several items including questionnaire item number 2 from 30 students, 8 people who answered "always" with a percentage of $26.67 \%$ and 12 students who said "sometimes". sometimes" with a percentage of $40.00 \%$, questionnaire item number 3 of 30 students 24 of them answered "never" with a percentage of $80.00 \%$, questionnaire item number 5 of 30 students 3 people answered "Yes" with a percentage of 10, 00\%, 9 people answered "sometimes" with a percentage of $30.00 \%$, and 15 students answered "never" with a percentage of $50.00 \%$, questionnaire item number 8 of 30 students 19 people answered "no" with a percentage of $63,34 \%$ of the questionnaire item number 10 of 30 students 19 people answered "Yes" with a percentage of $63.34 \%$ and 7 people who answered the category "sometimes" with a percentage of $23.33 \%$. Thus it can be concluded that, the effect of using gadgets on students' mindsets can be said that the average of student answers per questionnaire item given explains that students tend to always use gadgets and consider gadgets themselves as a necessity, but on the other hand students also consider that the use of gadgets is a necessity. These gadgets can be one of the motivations for student learning and can divide the time between the use of gadgets.
\end{abstract}

Key Word : Use Of Gadgets And Student Patterns

\section{PENDAHULUAN}

Kemajuan teknologi seperti televisi, handphone, laptop bahkan internet bukan hanya melanda masyarakat yang hidup di perkotaan namun dapat dinikmati oleh masyarakat yang hidup perkotaan namun dapat dinikmati masyarakat dipelosok-pelosok desa. Sebuah teknologi pada hakikatnya diciptakan untuk membuat hidup manusia menjadi semakin mudah dan nyaman. Kemajuan teknologi yang semakin pesat saat ini membuat hampir tidak ada bidang kehidupan manusia yang bebas dari penggunaannya, baik secara langsung maupun tidak langsung. Seiring arus globalisasi dengan tuntutan kebutuhan pertukaran informasi yang cepat, peranan teknologi komunikasi menjadi sangat penting.

$\begin{array}{llr}\text { Hassan } & (2015: \text { 17) } & \text { mengemukakan } \\ \text { teknologi } & \text { komunikasi } & \text { cenderung } \\ \text { memungkinkan terjadinya transformasi } & \text { tran } \\ \text { berskala luas dalam kehidupan manusia. } \\ \text { Transformasi tersebut telah memunculkan }\end{array}$

perubahan dalam berbagai pola hubungan antar manusia ( patterns of human communication), yang pada hakikatnya adalah interaksi antar pribadi (interpersonal relations ). Pertemuan tatap muka (face to face ) secara berhadapan dapat dilaksanakan dalam jarak yang sangat jauh melalui tahap citra (image to image).

Isi pesan media komunikasi seringkali tidak mempengaruhi masyarakat yang kini melainkan bentuk dan jenis media itu sendiri. Banyak bentuk-bentuk teknologi baru dalam komunikasi yang kita kenal, seperti telepon selular (gadget), surat elektronik, satelit, mesin faksm ili, dan lain-lain. Teknologi komunikasi dalam wujud gadget merupakan fenomena yang paling unik dan menarik dalam penggunaannya. Gadget yang mudah dibawa kemana saja kini tidak lagi mengenal usia dan kalangan, bahkan disebut sekarang ini gadget telah menjadi "teknologi yang merakyat". Penggunaan gadget menjadi kebutuhan yang sangat penting bagi kehidupan saat ini yang 
memerlukan mobilitas tinggi. Fasilitas-fasilitas yang terdapat didalamnya pun tidak hanya terbatas pada fungsi telepon dan SMS (short messages service) saja. Gadget dapat digunakan sebagai sarana bisnis, penyimpan berbagai macam data, sarana musik/hiburan, bahkan sebagai alat dokumentasi.

\section{Pengertian Media Teknologi Komunikasi (Gadget)}

\section{a. Teknologi Komunikasi}

Menurut Kamus Sosial Edisi Baru, istilah Teknologi yaitu : (1) Penerapan ilmu pengetahuan; (2) Pola praktek menggunakan semua sumber daya untuk mencapai tujuantujuan tertentu; serta (3) Semua ciri untuk mencapai tujuan organisasi. Sedangkan menurut Johannesen (2016 : 33) teknologi diartikan sebagai aktivitas budaya yang khas ketika manusia membentuk dan mengubah realitas alami demi tujuan-tujuan praktis. Setiap langkah kemajuan teknologi menyebabkan serangkaian perubahan yang berinteraksi dengan perubahan lainnya yang timbul dari sistem teknologi secara keseluruhan.

Bentuk-bentuk teknologi komunikasi menurut Kadir dan Triwahyuni (2016) mencangkup telepon, radio, dan televisi. Sedangkan dalam buku Human Communication (Tubbs dan Moss, 2014), bentuk-bentuk teknologi komunikasi ditampilkan dalam tingkat antarpesona, kelompok, organisasional, dan publik. Pada tingkat antarpersona yaitu telepon, telepon genggam ( handphone), surat elektronik, dan voicegram. Pada tingkat kelompok yaitu konferensi telepon, telekomunikasi komputer, dan surat elektronik. Pada tingkat organisasional yaitu interkom, konferensi telepon, surat elektronik, manajemen dengan bantuan komputer, sistem informasi, dan faksimili. Sedangkan pada tingkat publik yaitu televisi, radio, film, videotape, vidoedisc, TV kabel, TV satelit langsung, video dengan teks, teleteks, dan sistem informasi digital.

\section{b. Perkembangan Gadget}

Gadget atau bisa juga disebut Handphone (telepon genggam atau telepon seluler) merupakan telepon yang termasuk dalam sambungan telepon bergerak, dimana yang menghubungkan antar sesama gadget tersebut adalah gelombang-gelombang radio yang dilewatkan dari pesawat ke BTS (Base Tranceiver Station) dan MSC (Mobile Switching Center ) yang bertebaran di sepanjang jalur perhubungan kemudian diteruskan ke pesawat yang dipanggil (Gouzali Saydam,

\section{c. Fasilitas Pada Gadget.}

Disamping berfungsi sebagai alat komunikasi yang personal, gadget/gadget juga berpotensi sebagai sarana bisnis yang efektif. Gadget/gadget sangat bervariasi tergantung pada modelnya, yang seiring dengan perkembangan teknologi mempunyai fungsi-fungsi antara lain (Fiati, 2017:11) :

1. Penyimpan informasi

2. Pembuat daftar pekerjaan atau perencanaan kerja

3. Reminder (pengingat waktu) atau appointment

4. Alat perhitungan (kalkulator)

5. Pengiriman atau penerimaan e-mail

6. Permainan ( games )

7. Integrasi ke peralatan lain seperti PDA, MP3

8. Chatting dan Browsing internet

9. Video

\section{d. Dampak Penggunaan Gadget}

$$
\text { Menurut Badwilan (2014), }
$$

penggunaan gadget dapat membawa dampak-dampak tertentu. Dampak-dampak tersebut dibagi pada aspek psikologis, sosial, keuangan dan kesehatan atau keselamatan jiwa seseorang. Tetapi yang akan dijelaskan disini adalah pada aspek psikologis dan sosial (Badwilan, 2014):

a) Aspek Psikologis

Banyaknya pesan melalui SMS yang berisi ajakan-ajakan bersifat rasisme dapat mempengaruhi kondisi psikologis seseorang. Contohnya yang marak 
ditemukan adalah pesan yang berisi pemboikotan barang produksi Amerika. Selain itu juga terdapat peredaran pesan teks, gambar, maupun video yang bersifat pornografi. Mudahnya akses keluar-masuk pesan tersebut melalui gadget membawa dampak negatif, terutama untuk generasi muda sekarang ini.

b) Aspek Sosial

Salah satu hal yang sering terjadi adalah tindakan seseorang yang membiarkan gadget miliknya tetap dalam keadaan hidup atau aktif sehingga mengeluarkan bunyi yang nyaring. Hal ini jelas mengganggu konsentrasi serta mengejutkan orang-orang disekitarnya. Seperti ketika sedang rapat bisnis, di rumah sakit, sedang di tempattempat ibadah, dan lain-lain. Selain itu penggunaan gadget sebagai media komunikasi tidak langsung dapat menurunkan kualitas dan kuantitas dari komunikasi secara langsung (tatap muka). Sering terjadi kesalah pahaman dalam pemaknaan pesan melalui komunikasi secara tidak langsung.

\section{Pengertian Gadget}

Gadget merupakan sebuah inovasi dari teknologi terbaru dengan kemampuan yang lebih baik dan fitur terbaru yang memiliki tujuan maupun fungsi lebih praktis dan juga lebih berguna. Seiring perkembangan Pengertian Gadget pun menjadi berkembang yang sering kali menganggap smartphone adalah sebuah gadget dan juga teknologi komputer ataupunlaptop bila telah diluncurkan produk baru juga dianggap sebagai gadget.

Gadget (Bahasa Indonesia: acang) adalah suatu istilah yang berasal dari bahasa Inggris untuk merujuk pada suatu peranti atau instrumen yang memiliki tujuan dan fungsi praktis spesifik yang berguna yang umumnya diberikan terhadap sesuatu yang baru. Gadget Gratis dianggap dirancang secara berbeda dan lebih canggih dibandingkan teknologi normal yang ada pada saat penciptaannya.

\section{Jurnal Ilmiah Mandala Education}

\section{a. Perkembangan Teknologi Gadget dan Persebaran Konsumen}

Perkembangan teknologi TI yang begitu luar biasa membuat angka-angka di atas sangat mungkin meningkat tiap waktunya. Tak bisa dipungkuri dunia telah memasuki era baru, era digital yang segala sesuatunya terkoneksi lewat internet.

Sebagian besar alasan orangtua memberikan telepon genggam pada anakanaknya adalah agar ia mudah dihubungi atau tahu dimana keberadaan si anak. Tapi seringkali orangtua tidak menyadari hal-hal lain yang mungkin timbul saat anak diberikan handphone.

\section{b. Dampak Positif dan Negatif Gadget}

1) Dampak Positif

a) Mempermudah komunikasi.

b) Menambah pengetahuan tentang perkembangan teknologi.

c) Memperluas jaringan persahabatan.

2) Dampak Negatif

Walau memberi begitu banyak keuntungan bagi pemakainya, jika tidak bijak dalam penggunannya, gadget bisa memberi kerugian dengan canggihnya fitur-fitur yang tersedia di hand phone (HP) seperti : kamera, permainan (games) akan mengganggu siswa dalam menerima pelajaran di sekolah? Tidak jarang mereka disibukkan dengan menerima panggilan, sms, miscall dari teman mereka bahkan dari keluarga mereka sendiri.

\section{Definisi Berpikir}

\section{a. Pengertian Berpikir}

Definisi yang paling umum dari berfikir adalah berkembangnya ide dan konsep (Bochenski, dalam Suriasumantri (ed), 2014:52) di dalam diri seseorang. Perkembangan ide dan konsep ini berlangsung melalui proses penjalinan hubungan antara bagian-bagian informasi yang tersimpan di dalam diri seseorang yang berupa pengertian-pengertian.

Berpikir adalah suatu kegiatan mental yang melibatkan kerja otak. Walaupun tidak bisa dipisahkan dari 
aktivitas kerja otak, pikiran manusia lebih dari sekedar kerja organ tubuh yang disebut otak. Kegiatan berpikir juga melibatkan seluruh pribadi manusia dan juga melibatkan perasaan dan kehendak manusia. Memikirkan sesuatu berarti mengarahkan diri pada obyek tertentu, menyadari secara aktif dan menghadirkannya dalam pikiran kemudian mempunyai wawasan tentang obyek tersebut. Berpikir juga berarti berjerih-payah secara mental untuk memahami sesuatu yang dialami atau mencari jalan keluar dari persoalan yang sedang dihadapi. Dalam berpikir juga termuat kegiatan meragukan dan memastikan, merancang, menghitung, mengukur, mengevaluasi, membandingkan, menggolongkan, memilah-milah atau membedakan, menghubungkan, menafsirkan, melihat kemungkinankemungkinan yang ada, membuat analisisdan sintesis menalar atau menarik kesi mpulan dari premis-premis yang ada, menimbang, dan memutuskan.

\section{b. Karakteristik Pola Pikir}

Berpikir banyak sekali macamnya. Banyak para ahli yang mengutarakan pendapat mereka. Berikut ini akan dijelaskan macam-macam berpikir, yaitu :

a) Berpikir alamiah

Berpikir alamiah adalah pola penalaran yang berdasarkan kebiasaan sehari-hari dari pengaruh alam sekelilingnya, misal; penalaran tentang panasnya api yang dapat membakar jika dikenakan kayu pasti kayu tersebut akan terbakar.

b) Berpikir ilmiah

Berpikir ilmiah adalah pola penalaran berdasarkan sarana tertentu secara teratur dan cermat, misal; dua hal yang bertentangan penuh tidak dapat sebagai sifat hal tertentu pada saat yang sama dala satu kesatuan.

c) Berpikir autistik

Contoh berpikir autistik antara lain adalah mengkhayal, fantasi atau wishful thinking. Dengan berpikir autistik seseorang melarikan diri dari kenyataan, dan melihat hidup sebagai gambar-gambar fantastis.

d) Berpikir realistik

$$
\text { Berpikir dalam rangka }
$$
menyesuaikan diri dengan dunia nyata, biasanya disebut dengan nalar (reasoning). Floyd L. Ruch (2007) menyebutkan ada tiga macam berpikir realistic.

\section{KERANGKA PIKIR}

Gadget merupakan salah satu perkembangan teknologi komunikasi paling aktual di Indonesia selama lebih dari lima tahun terakhir.Tingkat penggunaan gadget pada remaja maupun siswa diduga dapat dipengaruhi oleh beberapa karakteristik, antara lain karakteristik yang berkaitan dengan diri individu (internal) maupun yang berkaitan dengan lingkungannya (eksternal).

Tujuan dalam menggunakan gadget diduga dapat mempengaruhi tingkat penggunaan gadget, karena dengan tujuan yang berbeda dapat menyebabkan perbedaan pula siswa menggunakan gadgetnya. Aktivitasaktivitas yang diikuti remaja maupun siswa diduga dapat mempengaruhi tingkat penggunaan gadget, karena dengan semakin banyak aktivitas atau kegiatan yang dilakukan dapat menunjukkan bahwa remaja maupun siswa tersebut memiliki mobilitas yang tinggi (di dalam maupun di luar sekolah).

Tingkat penggunaan gadget pada siswa maupun remaja dapat dilihat melalui empat hal, yaitu frekuensi penggunaan, pemanfaatan fasilitas, tingkat biaya pengeluaran, dan pihak yang diajak berkomunikasi.

Pola pikir dan interaksi sosial siswa secara tatap muka itu sendiri dilihat dari lamanya waktu serta intensitas (tingkat keluasan atau banyaknya topik pembicaraan) interaksi tatap muka. Berdasarkan literaturliteratur yang telah dibahas, maka dapat dirumuskan suatu kerangka pemikiran sebagai berikut: 
Skema Kerangka Pikir

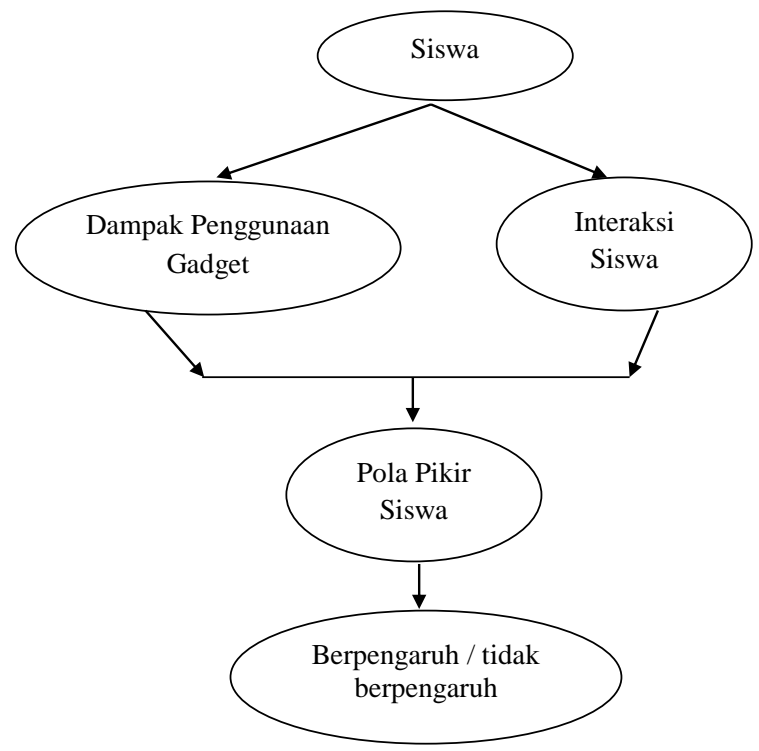

Gambar 2.1 Bagan Kerangka Pikir

\section{METODE PENELITIAN}

\section{a. Jenis Penelitian}

Jenis penelitian ini adalah penelitian deskriptif kuantitatif, penelitian ini dirancang secara deskriptif korelasional artinya peneliti hanya mendeskripsikan atau menggambarkan keadaan fenomena apa yang sebenarnya. Penelitian deskriptif korelasional dapat memastikan berapa besar pengaruh yang disebabkan oleh satu variabel dalam hubungannya dengan variasi yang disebabkan oleh variabel lain (Rakhmat, 2015).

\section{b. Populasi dan Sampel}

\section{Populasi}

Populasi dalam penelitian ini adalah siswa kelas VIII SMP Negeri 2 Ulaweng Kecamatan Ulaweng Kabupaten Bone yang terdiri dari dua kelas yang penyebarannya pada dua kelas yaitu pada kelas VIII A sebanyak 30 orang dan kelas VIII B 31 orang siswa.

\section{Sampel}

Pada penentuan sampel penulis hanya mengambil satu kelas dengan jumlah siswa 30 orang dengan jumlah siswa lakilaki 13 orang dan jumlah siswa perempuan 17 orang siswa.

\section{c. Instrumen Penelitian}

Instrumen penelitian adalah alat atau fasilitas yang digunakan peneliti dalam mengumpulkan data agar penelitiannya lebih mudah dan hasilnya lebih baik, yaitu lebih cermat, lengkap dan sistematis sehingga mudah diolah. Instrumen penelitian yang digunakan dalam penelitian ini, antara lain:

\section{Angket}

Angket adalah suatu teknik pengumpulan informasi yang memungkinkan analisis mempelajari sikasikap, keyakinan, perilaku dan karakteristik beberapa orang yang bisa terpengaruh oleh sistem yang diajukan atau yang sudah ada.

\section{Dokumentasi}

Dokumentasi digunakan untuk memperkuat data dan memberikan gambaran secara konkrit mengenai penelitian yang dilakukan.

\section{d. Teknik Pengumpulan Data}

Teknik pengumpulan data yang akan digunakan dalam penelitian ini adalah dengan angket dan dokumentasi.

\section{Angket (Kuesioner)}

Kuisioner atau angket adalah sejumlah pertanyaan atau pernyataan tertulis yang digunakan untuk memperoleh informasi dari responden. Dengan angket seseorang dapat diketahui tentang eadaan/data diri, pengalaman, pengetahuan, sikap, pendapat dan sebagainya.

2. Dokumentasi

Dokumentasi untuk menyelidiki benda-benda tertulis seperti buku-buku, majalah, dokumen, peraturan-peraturan, notulen rapat, catatan harian, bentuk gambar dan sebagainya (Suharsimi, 2013: 201).

\section{HASIL PENELITIAN Pembahasan}

Berdasarkan hasil penelitian yang telah dilaksanakan melalui angket yang telah diberikan kepada siswa tentang pengaruh penggunaan gadget terhadap pola pikir siswa dalam memahami materi pelajaran siswa kelas VIII SMP Negeri 2 Ulaweng Kecamatan Ulaweng Kabupaten Bone. Hasil analisis data 
Jurnal Ilmiah Mandala Education

http://ejournal.mandalanursa.org/index.php/JIME/index

Terakreditasi Peringkat 4 (No. SK: 36/E/KPT/2019)

di atas dapat dilihat bahwa dari skor tiap angket yang diberikan kepada masing-masing responden rata-rata menunjukkan jawaban dari setiap skor angket relatif setuju meskipun ada diantara skor angket yang menunjukkan jawaban relative tidak setuju. Hal tersebut dilihat dari persentase dan frekuensi dari jawaban tiap responden pada anket nomor 1 dengan item pertanyaan "Apakah anda menggunakan gadget" berdasarkan hasil penelitian yang telah diuraikan pada penjelasan sebelumnya bahwa rata-rata siswa menjawab "selalu" dengan frekuensi 17 orang siswa dengan persentase 56,67 \% hal tersebut menunjukkan bahwa rata-rata siswa menggunakan gadget. Penjelasan pada angket nomor 2 dengan item pertanyaan "Apakah pada saat anda belajar dirumah gadget di non aktifkan" berdasarkan hasil penelitian menunjukkan bahwa dari 30 orang siswa hanya 8 orang yang menjawab selalu dengan persentase $26,67 \%$ dan 12 orang siswa yang mengatakan kadang-kadang dengan persentase $40,00 \%$ hal ini menujukkan bahwa penggunaaan gadget pada saat belajar dirumah kecenderungan tidak di non aktifkan. Penjelasan pada angket nomor 3 dengan item pertanyaan "Apakah anda menggunakan gadget pada saat jam pelajaran disekolah" dari 30 orang siswa 24 orang diantaranya menjawab "tidak pernah" dengan persentase $80,00 \%$ hal ini menunjukkan bahwa meski penggunaan gadget tidak lepas dari keseharian siswa akan tetapi pada saat jam pelajaran di sekolah ratarata atau hampir seluruh siswa tidak pernah menggunakan gadget pada saat jam pelajaran disekolah. Penjelasan pada angket nomor 4 dengan item pertanyaan "menurut anda apakah gadget merupakan kebutuhan yang harus terpenuhi" dari 30 orang siswa 20 orang diantaranya menjawab "Ya" dengan persentase $66,67 \%$ dan 10 orang diantaranya menjawab kadang-kadang dengan persentase 33,33\% hal ini menunjukkan bahwa kecenderungan siswa menggunakan gadget sejalan dengan menjadikan penggunaan gadget sebagai kebutuhan dalam hal ini karena siswa merasa gadget merupakan kebutuhan yang harus terpenuhi. Penjelasan pada angket nomor 5 dengan item pertanyaan "Apakah penggunaan gadget membuat anda malas belajar" dari 30 orang siswa 3 orang menjawab "Ya" dengan persentase $10,00 \%, 9$ orang menjawab "kadang-kadang" dengan persentase 30,00\%, dan 15 orang siswa menjawab "pernah" dengan persentase $50,00 \%$. Hal ini menujukkab bahwa siswa merasa penggunaan gadget tidak membuat iswa itu sendiri malas belajar. Penjelasan pada angket nomor 6 dengan item pertanyaan "Apakah anda merasa ada perubahan yang positif setelah menggunakan gadget" dari 30 orang siswa 20 orang menjawab "Ya" dengan persentase $66,67 \%, 5$ orang diantaranya menjawab kadang-kadang dengan persentase $16,67 \%$ hal ini menunjukkan bahwa meskipun siswa kecenderungan menggunakan gadget tetapi siswa merasa bahwa ada perubahan yang positif setelah menggunakan gadget. Penjelasan pada angket nomor 7 dengan item pertanyaan "Apakah anda merasa ada perubahan yang negatif setelah menggunakan gadget" dari 30 orang siswa 23 orang menjawab "Tidak" dengan persentase 76,67\% hal ini menunjukkan bahwa meskipun siswa kecenderungan menggunakan gadget tetapi siswa merasa bahwa tidak ada dampak perubahan yang negatif dalam menggunakan gadget. Penjelasan pada angket nomor 8 dengan item pertanyaan "Apakah anda merasa dipengaruhi oleh gadget" dari 30 orang siswa 19 orang menjawab "tidak" dengan persentase $63,34 \%$ hal ini menunjukkan bahwa siswa yang menggunakan gadget merasa tidak terpengaruhi meskipun mereka menggunakan dan mejadikan gadget sebagi kebutuhan bagi siswa itu sendiri. Penjelasan pada angket nomor 9 dengan item pertanyaan "Apakah waktu belajar anda lebih banyak dibandingkan dengan memainkan gadget" dari 30 orang siswa 25 orang menjawab "Ya" dengan persentase $83,33 \%$, hal ini menunjukkan bahwa siswa memiliki waktu belajar lebih banyak dibandingkan dengan memainkan gadget. Penjelasan pada angket nomor 10 dengan item pertanyaan "Apakah gadget merupakan salah satu motivasi belajar anda" 
Jurnal Ilmiah Mandala Education

http://ejournal.mandalanursa.org/index.php/JIME/index

Terakreditasi Peringkat 4 (No. SK: 36/E/KPT/2019)
Vol. 7. No. 3 Agustus 2021

p-ISSN: 2442-9511 e-ISSN: 2656-5862 dari 30 orang siswa 19 orang menjawab "Ya" dengan persentase $63,34 \%$ dan 7 orang yang menjawab kategori "kadang-kadang" dengan persentase $23,33 \%$ hal ini menunjukkan bahwa siswa menjadikan gadget sebagai salah satu motivasi belajar siswa. Penjelasan pada angket nomor 11 dengan item pertanyaan "Apakah anda mengisi waktu anda dengan membahas pelajaran" dari 30 orang siswa 20 orang menjawab "Ya" dengan persentase 66,67 \% dan 5 orang menjawab dengan kategori "kadang-kadang" dengan persentase 16,67\% hal ini menunjukkan bahwa siswa masih memiliki waktu untuk membahas pelajaran. Penjelasan pada angket nomor 12 dengan item pertanyaan "Bisakah anda mengurangi sedikit kebiasaan memainkan gadget secara berlebihan" dari 30 orang siswa 18 orang menjawab "Ya" dengan persentase 60,00\% dan 12 orang menjawab dengan kategori "kadangkadang" dengan persentase $40,00 \%$ hal ini menunjukkan bahwa siswa bisa mengurangi sedikit kebiasaan memainkan gadget secara berlebihan. Penjelasan pada angket nomor 13 dengan item pertanyaan "Apakah anda bisa untuk sementara waktu tidak memegang gadget" dari 30 orang siswa 25 orang menjawab "Ya" dengan persentase $83,33 \%$ hal ini menunjukkan bahwa sebahagian besar siswa bisa untuk sementara waktu tidak memegang gadget. Penjelasan pada angket nomor 14 dengan item pertanyaan "Menurut anda apakah dengan mengikuti les-les diluar jam pelajaran sekolah dapat mengurangi kebiasaan memainkan gadget" dari 30 orang siswa 15 orang menjawab "Ya" dengan persentase 50,00 $\%$ dan 15 orang yang menjawab kategori "kadang-kadang" dengan persentase 50,00\% hal ini menunjukkan bahwa dengan mengikuti les-les diluar jam pelajaran sekolah dapat mengurangi kebiasaan memainkan gadget. Selanjutnya untuk penjelasan angket nomor 15 dengan item pertanyaan "Setujukah anda dengan larangan membawa gadget kesekolah" dari 30 orang siswa 18 orang menjawab "Setuju" dengan persentase $60,00 \%$ dan 5 orang yang menjawab kategori "Kurang setuju" dengan persentase $16,67 \%$ serta untuk kategori jawaban "Tidak setuju" ada 7 orang dengan persentase $23,33 \%$ hal ini menunjukkan bahwa pada dasarnya siswa setuju dengan adanya larangan membawa gadget disekolah.

\section{SIMPULAN}

Berdasarkan hasil penelitian yang telah peneliti lakukan di SMP Negeri 2 Ulaweng Kecamatan Ulaweng Kabupaten Bone tentang pengaruh penggunaan gadget terhadap pola pikir siswa kelas VIIIA SMP Negeri 2 Ulaweng Kecamatan Ulaweng Kabupaten Bone, maka akan penulis sajikan kesimpulannya. Adapun kesimpulan dalam penelitian ini menunjukan bahwa rata-rata siswa menjawab dari beberapa pilihan Angket siswa menjawab dengan opsi Ya dengan rata rata presentase diatas $56,6 \%$ kadang kadang Dengan rata rata $33,33 \%$ dengan demikian dapat disimpulkan bahwa, pengaruh penggunaan gadget terhadap pola pikir siswa bahwa rata-rata dari jawaban siswa per item angket yang diberikan menjelaskan siswa cenderung selalu menggunakan gadget dan menganggap bahwa gadget itu sediri sebagai kebutuhan tetapi dilain sisi pula siswa menganggap bahwa penggunaan gadget tersebut bisa menjadi salah satu motivasi belajar siswa dan bisa membagi waktu antara penggunaan gadget dengan belajar.

\section{Saran}

Berdasrkan hasil penelitian yang peneliti peroleh maka terdapat beberapa saran antara lain :

\section{Bagi Guru}

a) Bagi Guru-guru lebih kreatif dalam mengajar.

b) Guru harus terampil demi terlaksanakannya proses belajar mengajar serta dapat memanfaatkan sarana dan prasarana yang ada.

c) Guru dengan siswa harus ada komunikasi dan kedekatan dengan siswa agar dapat mengetahui karakter siswa dalam belajar sehingga guru bisa mengimbanginya dengan mengemas pembelajaran yang menyenangkan agar siswa dapat pula 
d) terhidar dari penggunaan gadget yang cenderung menguasai siswa dalam hal peggunaannya.

2. Bagi Sekolah

a) Sekolah memberikan sarana dan prasarana yang cukup memadai

b) Sekolah berperan aktif dengan mengikutsertakan guru dalam pelatihan-pelatihan dan mengadakan studi banding di sekolah-sekolah yang dirasa lebih unggul, hal ini sebagai bekal keilmuan guru dalam perkembangan pembelajaran.

c) Mendukung guru-guru untuk mengembangkan macam-macam model pembelajaran dalam proses pembelajaran agar selalu ada peningkatan

\section{DAFTAR PUSTAKA}

Badwilan, Rayyan Ahmad. 2014. Rahasia Dibalik Handphone. Jakarta : Darul Falah,

Brotosiswoyo, B. Suprapto. 2017. 'Dampak Sistem Jaringan Global Pada Pendidikan Tinggi : Peta Permasalahan'. Komunika. Tangerang : Universitas Terbuka

Fiati, Rina. 2017. Akses Internet Via Ponsel. Yogyakarta : Penerbit Andi Yogyakarta. Hassan, Fuad, 2015. Teknologi Dan Dampak Kebudayaannya: Tantangan Dalam Laju Teknologi. Orasi Ilmiah Dies Natalis Institut Teknologi.

Johannesen, Richard L. 2016.Etika Komunikasi. Bandung : PT Remaja Rosdakarya.

Rakhmat, Jalaluddin.2015. Psikologi Komunikasi. Edisi Revisi. Bandung : PT Remaja Rosdakarya.

Saydam, Gouzali. 2015. Teknologi Telekomunikasi, Perkembangan dan Aplikasi. Bandung: Alfabeta.

Shiroth, Muhammad \& Nur Mohammad Amin. 2014. Trend Industri Telekomunikasi di Indonesia. Depok : Fakultas Ekonomi UI.
Simanjuntak, Fritz E. 2015. Aspek Sosial Telepon Selular. www.kompas.com. 13 Mei 2004

Suharsimi, 2013. Sistem-Sistem Komunikasi di Indonesia. Jakarta : PT Raja Grafindo Persada.

Suriasumantri, 2014. Pengenalan Teknologi Informasi. Yogyakarta : Penerbit Andi Yogyakarta

Triwahyuni, 2016.. 'Pengembangan Sistem Informasi: Permasalahan Dan Prospeknya'. Jakarta : Ghalia Indonesia

Tubbs dan Moss, 2014. Psikologi Perkembangan, Suatu Pendekatan Sepanjang Rentang Kehidupan. Jakarta : Erlangga.

Tubbs, Steward L \& Sylvia Moss, 2016. Human Communication, Kontekskonteks Komunikasi. Cetakan Ketiga. Bandung : PT Remaja Rosdakarya. 